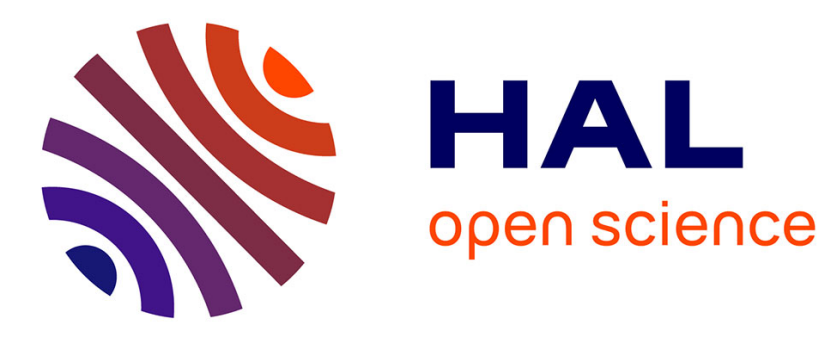

\title{
$\beta$-Arrestin2 plays a key role in the modulation of the pancreatic beta cell mass in mice
}

Magalie A Ravier, Michèle Leduc, Joy Richard, Nathalie Linck, Annie

Varrault, Nelly Pirot, Morgane Roussel, Joël Bockaert, Stéphane Dalle, Gyslaine Bertrand

\section{To cite this version:}

Magalie A Ravier, Michèle Leduc, Joy Richard, Nathalie Linck, Annie Varrault, et al.. $\beta$-Arrestin2 plays a key role in the modulation of the pancreatic beta cell mass in mice. Diabetologia, 2014, 57 (3), pp.532-541. 10.1007/s00125-013-3130-7 . hal-02506326

\section{HAL Id: hal-02506326 \\ https://hal.umontpellier.fr/hal-02506326}

Submitted on 23 Mar 2020

HAL is a multi-disciplinary open access archive for the deposit and dissemination of scientific research documents, whether they are published or not. The documents may come from teaching and research institutions in France or abroad, or from public or private research centers.
L'archive ouverte pluridisciplinaire HAL, est destinée au dépôt et à la diffusion de documents scientifiques de niveau recherche, publiés ou non, émanant des établissements d'enseignement et de recherche français ou étrangers, des laboratoires publics ou privés. 


\section{Article \\ $\beta$-arrestin2 plays a key role in the \\ modulation of the pancreatic beta cell mass in mice}

Magalie A. Ravier ${ }^{1-3}$, Michele Leduc ${ }^{1-3}$, Joy Richard ${ }^{1-3}$, Nathalie Linck $^{1-3}$, Annie Varrault ${ }^{1-3}$,

Nelly Pirot ${ }^{4,5}$, Morgane M. Roussel ${ }^{1-3}$, Joël Bockaert ${ }^{1-3}$, Stéphane Dalle ${ }^{1-3}$ and Gyslaine Bertrand $^{1-3}$

1. CNRS, UMR-5203, Institut de Génomique Fonctionnelle, 141 Rue de la Cardonille, 34094 Montpellier, France

2. Inserm, U661, Institut de Génomique Fonctionnelle, Montpellier, France

3. Universités de Montpellier 1 \& 2, Institut de Génomique Fonctionnelle, Montpellier, France

4. Inserm, U896, Institut de Recherche en Cancérologie de Montpellier, Centre Régional de Lutte Contre le Cancer Val d'Aurelle Paul Lamarque, 34298 Montpellier, France

5. Université Montpellier 1, Institut de Recherche en Cancérologie de Montpellier, Montpellier, France

Corresponding author: G. Bertrand, CNRS, UMR-5203, Institut de Génomique Fonctionnelle, 141 Rue de la Cardonille, 34094 Montpellier, France email gyslaine.bertrand@igf.cnrs.fr 


\begin{abstract}
Aims/hypothesis Beta cell failure due to progressive secretory dysfunction and limited expansion of beta cell mass is a key feature of type 2 diabetes. Beta cell function and mass are controlled by glucose and hormones/neurotransmitters that activate $G$ protein-coupled receptors or receptor tyrosine kinases. We have investigated the role of $\beta$-arrestin (ARRB)2, a scaffold protein known to modulate such receptor signalling, in the modulation of beta cell function and mass, with a specific interest in glucagon-like peptide-1 (GLP-1), muscarinic and insulin receptors.
\end{abstract}

Methods $\beta$-arrestin2-knockout mice and their wild-type littermates were fed a normal or a high-fat diet (HFD). Glucose tolerance, insulin sensitivity and insulin secretion were assessed in vivo. Beta cell mass was evaluated in pancreatic sections. Free cytosolic $\left[\mathrm{Ca}^{2+}\right]$ and insulin secretion were determined using perifused islets. The insulin signalling pathway was evaluated by western blotting.

Results Arrb2-knockout mice exhibited impaired glucose tolerance and insulin secretion in vivo, but normal insulin sensitivity compared with wild type. Surprisingly, the absence of ARRB2 did not affect glucose-stimulated insulin secretion or GLP-1- and acetylcholinemediated amplifications from perifused islets, but it decreased the islet insulin content and beta cell mass. Additionally, there was no compensatory beta cell mass expansion through proliferation in response to the HFD. Furthermore, Arrb2 deletion altered the islet insulin signalling pathway.

Conclusions/interpretation ARRB2 is unlikely to be involved in the regulation of insulin secretion, but it is required for beta cell mass plasticity. Additionally, we provide new insights into the mechanisms involved in insulin signalling in beta cells.

Keywords: $\beta$-Arrestin, GLP-1, High-fat diet, Insulin secretion, Pancreatic beta cell mass, Pancreatic islet biology 


\section{Abbreviations}

$\mathrm{ACh}$

ARRB

AU

$\left[\mathrm{Ca}^{2+}\right]_{\mathrm{c}}$

FOXO1

GIPR

GLP-1R

GPCR

GSIS

GSK3

$\mathrm{H} \& \mathrm{E}$

HFD

IR

ND

PDX1

PI3K

RTK
Acetylcholine

$\beta$-Arrestin

Arbitrary units

Free cytosolic $\mathrm{Ca}^{2+}$ concentration

Forkhead box O1

Gastric inhibitory polypeptide receptor

Glucagon-like peptide-1 receptor

G protein-coupled receptor

Glucose-stimulated insulin secretion

Glycogen synthase kinase 3

Haematoxylin and eosin

High-fat diet

Insulin receptor

Normal diet

Pancreas/duodenum homeobox protein 1

Phosphatidylinositol 3-kinase

Receptor tyrosine kinase 


\section{Introduction}

Type 2 diabetes is characterised by a chronic hyperglycaemia due to defects in both insulin sensitivity and secretion. It is now established that beta cell failure results from a progressive secretory dysfunction and a limited expansion of the beta cell mass [1-3]. Beta cell function and mass are tightly controlled by glucose and are modulated by hormones and neurotransmitters that activate $\mathrm{G}$ protein-coupled receptors (GPCRs) or receptor tyrosine kinases (RTKs) [4,5]. The neurohormonal amplification of glucose-stimulated insulin secretion (GSIS) and also beta cell mass adaptation are mainly controlled by the incretin gastrointestinal hormone glucagon-like peptide-1 (GLP-1) and the parasympathetic neurotransmitter acetylcholine (ACh), which both act through the activation of GPCRs $[4,6,7]$. The incretin GLP-1 binds the specific GLP-1 receptor (GLP-1R) that is positively coupled to the adenylyl cyclase through Gas, leading to cAMP production [8]. ACh binds to M3 muscarinic receptors [6,9] that are coupled via Gq/11-proteins to phospholipase C. This results, on one hand, in inositol 1,4,5-triphosphate production and $\mathrm{Ca}^{2+}$ mobilisation from the endoplasmic reticulum and, on the other hand, to diacylglycerol production and protein kinase $\mathrm{C}$ activation [6]. In addition, several lines of evidence suggest a direct autocrine effect of insulin on beta cells [5,10-12]. The insulin signalling pathway is mainly mediated through the insulin receptor (IR)/IRS/phosphatidylinositol 3-kinase (PI3K)/Akt cascade [5,11,13]. It plays a critical role in the maintenance of the beta cell mass and a role in its own secretion has also been proposed [5,10-12].

The $\beta$-arrestins (ARRBs) are ubiquitously expressed cytosolic proteins that were originally identified as negative regulators of GPCR signalling via desensitisation and internalisation processes. However, it is now well established that ARRBs can also act as multifunctional scaffolding proteins to elicit G-protein-independent signalling pathways by linking the activated GPCRs to various additional catalytically active effectors [14-17], and are strongly involved in several GPCR-mediated physiological effects [16,18]. The two 
ARRBs isoforms, ARRB1 and ARRB2, share a high degree of structural homology, but they display specific functions in several physiological processes [16-19]. In addition, the roles of ARRBs are not only restricted to the regulation of GPCRs but also extend to RTK signalling pathways $[14,20]$. Indeed, insulin has been shown in hepatocytes to promote the formation of a signalling complex in which ARRB2 was required to scaffold Src and Akt to the IR to ensure a full Akt activation [21].

We and others have shown that ARRB1 mediates GPCR signalling for GLP-1 [22-25], pituitary adenylate cyclase-activating polypeptide (PACAP) [25] and M3 muscarinic agonists [26], and could be involved in the regulation of insulin secretion as well as beta cell survival and proliferation [27]. By contrast, little is known concerning the role of ARRB2 in beta cells. Only a recent study has reported that its deletion impaired glucose-induced insulin secretion in mice [28], though the impact on agonist-activated GPCRs and RTKs was not explored. In the present study, we have used Arrb2-knockout $\left(A r r b 2^{--}\right)$mice to investigate the impact of Arrb2 deletion on beta cell function and mass, with a specific interest in GLP-1, M3 and IR.

\section{Methods}

Materials The sources of primary and secondary antibodies used are listed in the electronic supplementary material (ESM) Table 1. GLP-1 was from Bachem (Bubendorf, Switzerland). The PP2 and protease inhibitor mixture were from Calbiochem (La Jolla, CA, USA). All other chemical reagents were purchased from Sigma-Aldrich (St Louis, MO, USA).

Animals The original heterozygous $\left(A r r b 2^{+/-}\right)$mice were obtained from R. J. Lefkowitz (Duke University Medical Center, Durham, NC, USA). Mice were subsequently backcrossed onto C57BL/6J background (Charles River, Lyon, France). Arrb2 ${ }^{-/-}$mice and their wild-type littermates $\left(\mathrm{Arrb2}^{+/+}\right)$were generated by breeding heterozygous animals. Mouse genotyping was performed by PCR (ESM Fig. 1a) and verified by western blot (ESM Fig. 1b). All animal studies complied with the authorisation of the Ministry of Agriculture, France (D34-172-13). 
The mice were fed either with a standard normal diet (ND, 5\% kJ\% fat), or a high-fat diet (HFD, 45\% kJ\% fat; D12451; Research Diets, New Brunswick, NJ, USA). Except when stated, all experiments were performed using 6- to 7-month-old female mice.

Glucose and insulin tolerance test measurements Glucose tolerance tests were performed on overnight-fasted mice by i.p. injection of glucose or by re-feeding tests. Insulin tolerance tests were performed on mice fasted for 4 h by i.p. injection of insulin (Umuline, Lilly, Giessen, Germany). Blood glucose levels were measured using an OneTouch Ultra glucometer (LifeScan, Issy les Moulineaux, France). Plasma insulin and glucagon levels were determined using a sensitive rat insulin and glucagon RIA kits (Millipore, St Charles, MO, USA).

Islet isolation Islets were isolated after collagenase digestion of the pancreas [25], and were used either immediately after isolation or after an overnight culture in RPMI-1640 containing $10 \mathrm{mmol} / \mathrm{l}$ glucose and $7.5 \%$ (vol/vol) FCS. The medium used for the experiments was a bicarbonate KRB supplemented with $1.1 \mathrm{mmol} / 1$ glucose [25].

Free cytosolic $\mathrm{Ca}^{2+}$ concentration, insulin secretion and content measurements For free cytosolic $\mathrm{Ca}^{2+}$ concentration $\left(\left[\mathrm{Ca}^{2+}\right]_{\mathrm{c}}\right)$, cultured islets were loaded with $2 \mu \mathrm{mol} / \mathrm{l}$ Fura2-LeakResistant-AM (Tef Labs, Austin, TX, USA) for $2 \mathrm{~h}$, placed into a temperature-controlled perifusion chamber and excited every $3 \mathrm{~s}$ at 340 and $380 \mathrm{~nm}$; the emitted light was recorded at $510 \mathrm{~nm}$. Insulin secretion from cultured islets was examined by perifusion or static incubation [29]. Islet or pancreas insulin content was determined after extraction in acid-ethanol. Insulin concentrations were determined using a rat insulin RIA kit (Millipore).

Western blot Immunoblots were performed on cell lysates from pancreatic islets as previously described [25]. Briefly, freshly isolated islets were harvested in cold lysis buffer and equal amounts of proteins were subjected to western blotting [25] with primary antibodies of interest (ESM Table 1). 
Real-time quantitative RT-PCR Total RNA from mouse islets was extracted and DNasetreated using the RNAeasy microkit (Qiagen, Courtaboeuf, France), according to the manufacturer's instructions. Real-time quantitative RT-PCR experiments were performed as previously described [25]. Primer sequences are listed in ESM Table 2.

Histological analysis and immunostaining of pancreases Pancreases were spread into flat embedding cassettes, fixed with $4 \%$ (vol/vol) paraformaldehyde, paraffin embedded and longitudinally sectioned through the pancreatic head-to-tail axis (4 $\mu \mathrm{m}$ thickness). Three pancreatic sections per mouse, separated by at least $100 \mu \mathrm{m}$, were stained with haematoxylin and eosin (H\&E), and scanned using a NanoZoomer slide scanner (Hamamatsu Photonics, Hamamatsu City, Japan). The islet numbers were quantified and the area of each islet was measured with the NDP.view software, version 1.2 (http://ndpview.software.informer.com/1.2/). For immunohistochemistry, deparaffinised pancreatic sections were boiled in $10 \mathrm{mmol} / \mathrm{l}$ citrate buffer for $30 \mathrm{~min}$ before blocking with $1 \% \mathrm{BSA}$ PBS $30 \mathrm{~min}$ at room temperature. Sections were incubated overnight at $4^{\circ} \mathrm{C}$ with primary antibodies (ESM Table 1), followed by $1 \mathrm{~h}$ at room temperature with secondary antibodies (ESM Table 1) and DAPI. Sections were mounted in Mowiol (Sigma-Aldrich) and imaged using a Zeiss AxioImager microscope (Carl Zeiss, Marly le Roi, France).

Statistical analysis Data are presented as mean \pm SEM. Statistically significant differences between groups were assessed by Student's $t$ test or by ANOVA, followed by the NewmanKeuls test or a Bonferroni post test for multiple comparisons using GraphPad Prism software version 5.0 (http://www.graphpad.com/scientific-software/prism/). Differences were considered significant at $p<0.05$.

\section{Results}

Arrb2 $2^{-1-}$ mice displayed glucose intolerance and reduced plasma insulin responses Body weight (not shown) and food intake (ESM Fig. 2b) were not significantly different between 
$\mathrm{Arrb}^{+/+}$and $\mathrm{Arrb2} 2^{-/-}$mice, but $\mathrm{Arrb2} 2^{-{ }_{-}}$mice displayed glucose intolerance. Indeed, after an i.p. glucose injection, blood glucose levels were higher at 15 and $30 \mathrm{~min}$ (Fig. 1a) in Arrb2 $2^{-/-}$ vs $\mathrm{Arrb2}^{+/+}$mice, while insulin tolerance tests showed similar insulin sensitivities (Fig. 1b). By contrast, glucose intolerance was associated with decreased plasma insulin levels 15 min after the i.p. injection of glucose (Fig. 1c). Similarly, fasted (Fig. 1f), postprandial (re-fed; Fig. 1f) and fed (Fig. 1d) blood glucose levels were increased while plasma insulin levels were reduced in re-fed and fed states (Fig. 1e, g) in Arrb2 $2^{-/-}$vs $A r r b 2^{+/+}$mice. However, there were no significant differences in fed plasma glucagon levels between $A r r b 2^{-/-}$and $A r r b 2^{+/+}$ mice $\left(0.024 \pm 0.003\right.$ vs $0.028 \pm 0.003 \mathrm{pmol} / 1$, respectively). Therefore, Arrb2 ${ }^{-/-}$mice displayed glucose intolerance associated with decreased plasma insulin levels, suggesting reduced insulin secretion rather than defective insulin action.

Arrb2 $2^{-1-}$ islets displayed normal glucose-induced insulin secretion but lower islet insulin content To determine if ARRB2 was involved in beta cell secretory function, both free cytosolic $\mathrm{Ca}^{2+}\left(\left[\mathrm{Ca}^{2+}\right]_{\mathrm{c}}\right)$ changes and insulin release were evaluated in vitro in response to glucose in isolated islets. An increase in glucose concentration from 1.1 to $16.7 \mathrm{mmol} / \mathrm{l}$ triggered the classic biphasic changes in $\left[\mathrm{Ca}^{2+}\right]_{\mathrm{c}}$ in both $A r r b 2^{+/+}$and $A r r b 2^{-/-}$islets (Fig. 2a). Neither the increases in $\left[\mathrm{Ca}^{2+}\right]_{\mathrm{c}}$ (Fig. 2a) nor $\left[\mathrm{Ca}^{2+}\right]_{\mathrm{c}}$ oscillations (Table 1) were affected in perifused $A r r b 2^{-/-}$mouse islets. Additionally, insulin secretion was not affected when expressed as pg/islet (Fig. 2b) or when the amount of secreted insulin was normalised to the islet insulin content (Fig. 2c). Similar results have been obtained from static islet incubations with various glucose concentrations (ESM Fig. 3). This indicates a preserved beta cell secretory function in response to glucose in $A r r b 2^{-/-}$islets. By contrast, the insulin content was significantly lower in $A r r b 2^{-/-}$compared with $A r r b 2^{+/+}$mice in size-matched isolated islets (20\%) (Fig. 2d) and in the whole pancreas (27\%) (Fig. 2e). Furthermore, Ins2 mRNA levels were lower in $A r r b 2^{-/-}$islets (28\%) (Fig. 2f) without a significant alteration of Ins1 


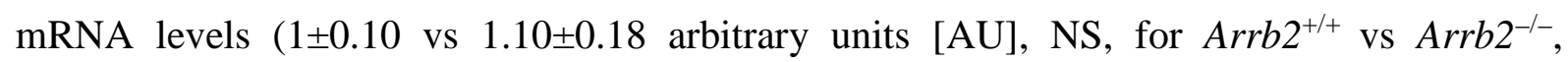
respectively). Taken together, these results indicate $A r r b 2^{-/}$islets showed a decreased insulin expression but normal beta cell secretory function in response to glucose.

Arrb2 $2^{-1-}$ islets displayed normal GLP-1- and ACh-induced insulin secretion As ARRBs are well known for their role in GPCR signalling [14-16], isolated islets were subjected to GLP-1 or ACh stimulation. GLP-1 (20 nmol/l) increased the frequency and reduced the amplitude of glucose-induced oscillations of $\left[\mathrm{Ca}^{2+}\right]_{\mathrm{c}}$ in $A r r b 2^{+/+}$islets (Fig. 3a, Table 1). The amplitude decrease was mainly due to the increased nadir level of the $\left[\mathrm{Ca}^{2+}\right]_{\mathrm{c}}$ oscillations (Table 1). Interestingly, no significant differences could be observed under GLP-1-induced $\left[\mathrm{Ca}^{2+}\right]_{\mathrm{c}}$ changes between $A r r b 2^{-/-}$and $A r r b 2^{+/+}$islets (Fig. 3a, Table 1). Additionally, GLP-1 potentiated GSIS similarly in $A r r b 2^{-/-}$and $A r r b 2^{+/+}$islets during perifusion (Fig. 3b) and static incubations (ESM Fig. 3). Similarly, ACh $(1 \mu \mathrm{mol} / \mathrm{l})$ induced a comparable sustained $\left[\mathrm{Ca}^{2+}\right]_{\mathrm{c}}$ plateau which was either flat or superimposed with fast oscillations (Fig. 3c, Table 2), and potentiated insulin secretion in $\mathrm{Arrb}^{-/-}$islets to a similar extent as in $\mathrm{Arrb2}{ }^{+/+}$islets (Fig. 3d). Therefore, ARRB2 is not involved in the regulation of GSIS or in the response to GLP-1 or ACh.

Arrb2 $2^{-1-}$ mice displayed a reduced pancreatic beta cell mass The lower pancreatic insulin content of $\mathrm{Arrb}^{-/-}$mice could result not only from impaired preproinsulin gene transcription (reduced Ins 2 mRNA levels) but also from a reduced beta cell mass. Morphometric histological analysis of pancreatic sections showed no differences in islet number (Fig. 4a, b), while the proportion of islet occupation per section (i.e. islet area) was decreased by $\sim 30 \%$ in $A r r b 2^{-/-}$pancreases (Fig. 4a, c), due to a modified distribution of the islet sizes (increased amount of smaller islets and reduced amount of large islets) (Fig. 4d). Immunohistochemical staining for insulin and glucagon and cell nuclei number counting did not show any 
abnormalities in islet architecture (Fig. 4e) but, in keeping with reduced islet size, indicated a decrease in beta cell (35\%) but no change in alpha cell number (Fig. 4f), resulting in a relative significant enrichment in islet alpha cells $(23.51 \pm 0.85$ vs $28.90 \pm 1.38 \%, \mathrm{p}<0.001)$ in $\mathrm{Arrb} 2^{-/-}$ pancreases. In addition, beta cell size did not differ significantly between $A r r b 2^{-/-}$and Arrb2 $2^{+/+}$mice (Fig. 4g).

ARRB2 is involved in the insulin signalling pathway in pancreatic islets Numerous studies have documented the role of insulin through the IR/PI3K/Akt pathway for the expansion of the beta cell mass $[5,10,11]$. ARRB2 has been shown to be involved in the regulation of the insulin signalling pathway in liver by scaffolding c-Src and Akt to the IR, allowing full Akt activation [21], and we observed that ARRB2 plays a key role in the modulation of the beta cell mass. Therefore, we have investigated whether ARRB2 could be involved in the regulation of the insulin signalling pathway in islets. In $A r r b 2^{+/+}$islets, insulin $(100 \mathrm{nmol} / \mathrm{l})$ induced a clear Akt phosphorylation ( 1.7-fold increase), which was strongly reduced in Arrb2 ${ }^{-/-}$mouse islets $(\mathrm{p}<0.001)$ (Fig. 5). Moreover, insulin-induced phosphorylation of the transcription factor Forkhead box O (FOXO)1 and the glycogen synthase kinase 3 (GSK3) $\beta$, two major downstream targets of Akt, were also markedly reduced (Fig. 5). Taken together, our results establish for the first time that ARRB2 contributes to the insulin signalling pathway in islets.

Arrb2 $2^{-1-}$ mice were unable to compensate their beta cell mass under HFD Diet-induced obesity leads to insulin resistance and to a compensatory increase in beta cell mass [2,30,31]. Thus, to explore the potential role of ARRB2 in the compensatory beta cell mass expansion,

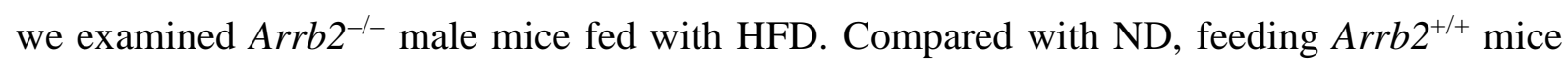
with an HFD for 19 weeks resulted in an insulin-resistant phenotype, characterised by higher weight gain (ESM Fig. 2a) for a similar food intake (ESM Fig. 2b), elevated fasted (ESM Fig. 2c) and fed (ESM Fig. 2d) blood glucose and fed plasma insulin levels (ESM Fig. 2e). 
$\mathrm{Arrb}^{-{ }^{-}}$mice displayed similar increases in weight gain (ESM Fig. 2a) and food intake (ESM Fig. 2b) to Arrb2 $2^{+/+}$mice. Additionally, HFD similarly enhanced blood glucose levels in $A r r b 2^{-/-}$and $A r r b 2^{+/+}$mice (ESM Fig. 2c, d), but Arrb2 $2^{-/-}$mice exhibited a clearly lower increase in plasma insulin levels (ESM Fig. 2e). Morphometric analysis of pancreatic sections showed that while Arrb2 $2^{+/+}$littermates displayed a doubling of their islet area occupation per section (Fig. 6a) and an increase in islet number (Fig. 6b), Arrb2 $2^{-/-}$mice were unable to compensate these variables or, therefore, their islet mass under the HFD (Fig. 6a, b). As expected, beta cell mass (Fig. 6d, f) and proliferation (Ki67-positive beta cells) (Fig. 6g) were both increased in $A r r b 2^{+/+}$islets under the HFD, while both variables remained unchanged in Arrb2 $2^{-/-}$islets (Fig. 6d-g).

\section{Discussion}

ARRB1 and ARRB2 play key roles in various receptor functions by acting as either GPCR desensitisers or signal transducers through the coupling of activated GPCRs or RTKs to additional non-canonical signalling pathways. Beta cell function and mass are tightly controlled by glucose and are modulated by GPCRs and RTKs. The neurohormonal amplification of GSIS and beta cell mass adaptation are ensured mainly by GPCRs such as GLP-1 and M3 muscarinic receptors, but also by RTKs such as IRs. In this study, we have used $A r r b 2^{-/-}$mice to assess the role of ARRB2 in beta cell function and mass, with a specific interest in GLP-1 and ACh actions, and have addressed its potential implication in the insulin signalling pathway. Our study shows that Arrb2 deletion in mice did not impact on GSIS or GLP-1 and ACh responses in vitro, but it reduced beta cell mass in normal conditions and avoided its compensatory increase under an HFD. Furthermore, the absence of ARRB2 altered the islet insulin signalling pathway.

Our Arrb2 ${ }^{-/-}$mice were mildly glucose intolerant, with higher fasted and postprandial blood glucose levels. Nevertheless, despite their higher blood glucose levels, Arrb2 ${ }^{-{ }_{-}}$mice 
exhibited lower amount of plasma insulin in response to glucose load in the re-fed and fed ad libitum states, but displayed similar insulin sensitivities to $A r r b 2^{+/+}$mice. Therefore, the in vivo glucose intolerance in $A r r b 2^{-/-}$mice was likely to have been caused by an insufficient insulin release in response to glucose rather than insulin resistance. In spite of the lower plasma insulin, which suggests a beta cell defect, glucose-induced $\left[\mathrm{Ca}^{2+}\right]_{\mathrm{c}}$ changes and GSIS (normalised to $\%$ of content) were similar in isolated islets from $A r r b 2^{-/-}$and $A r r b 2^{+/+}$mice. Moreover, the ability of ACh and GLP-1 to modulate $\left[\mathrm{Ca}^{2+}\right]_{\mathrm{c}}$ changes and potentiate GSIS was unaffected in $A r r b 2^{-/-}$islets, indicating that ARRB2 is unlikely to play a crucial role in GSIS and the amplification mediated by GLP-1R and M3 muscarinic receptors. Conflicting results have been reported concerning the interactions of ARRB2 and GLP-1R. Indeed, it has been shown in HEK293 cells that, on GLP-1 activation, ARRB2 was not recruited to the receptor and consequently was not involved in GLP-1R endocytosis [32]. Others have reported that ARRB2 was recruited to the activated GLP-1R and that the interaction markedly reduced G protein-mediated cAMP accumulation [33,34]. Furthermore, in HEK293T, GLP-1mediated ARRB2 recruitment was decreased when GLP-1R were co-expressed with gastric inhibitory polypeptide receptors (GIPRs), suggesting that GLP-1/GIP receptor heteromerisation protected from receptor desensitisation [35]. As both GIPR and GLP-1R are highly co-expressed in beta cells [8], such mechanisms could explain the lack of effects of Arrb2 deletion on GLP-1-potentiated GSIS in our study. Additionally, the lack of ARRB2 could be compensated by ARRB1, the other isoform. However, it should be noted that we did not observe any compensatory increases in Arrbl mRNA levels in Arrb2 ${ }^{-1-}$ islets (not shown), and that despite their high structural homology, ARRB1 and ARRB2 are not often functionally redundant, but exerts specific functions [16,18]. In that sense, and in contrast to ARRB2, we and others have shown that ARRB1 is involved in GLP-1 [22,23,25] and M3 [26] receptor signalling pathways for the stimulation of insulin secretion [27].

By contrast, if we have observed that ARRB2 is unlikely to play a crucial role in GSIS and 
in the amplification mediated by GLP-1R and M3 muscarinic receptors, Arrb2 deletion decreased total pancreas and islet insulin content, and decreased the beta cell mass. This may explain the lowered plasma insulin levels recorded in vivo in $A r r b 2^{-/-}$mice. The decreased insulin content was associated with a reduced expression of Ins 2 but not Ins 1 mRNA levels. This differential regulation of Ins 2 and Ins 1 genes has been reported by others [36-38]. Moreover, Arrb2 $2^{--}$mice under the ND displayed a relatively lower islet size (due to an increased amount of small islets and a reduced amount of large islets), associated with a decrease in beta cell number, suggesting that ARRB2 is required for the maintenance of mouse beta cell mass in vivo. In adults, the beta cell mass is stable because of a slow turnover rate, but it displays dynamic plasticity when needed to compensate for differing insulin requirements of the organism. Thus, in most situations of insulin resistance, such as obesity, there is a compensatory increase in beta cell mass, where beta cell proliferation plays a key role [11,39-41]. In agreement with previous reports, we observed that C57BL/6J mice fed with a moderate increase in dietary fat (45\%) displayed higher body weight gain and moderate hyperglycaemia and hyperinsulinaemia. In addition, Arrb2 $2^{+/+}$mice under the HFD showed a compensatory increase in beta cell mass due to proliferation (i.e. increase in Ki67positive beta cells). In our study no change in beta cell size was observed, suggesting that hyperplasia, rather than hypertrophy, was involved. By contrast, Arrb2 $2^{-/}$mice under the HFD did not display a compensatory increase in beta cell mass, and this inability was correlated with no increase in beta cell proliferation. Our study shows for the first time that ARRB2 is required not only for the maintenance of the beta cell mass under normal conditions but also for the compensatory beta cell mass expansion under conditions where the insulin demand is increased.

As ARRB2 is ubiquitously expressed, the defective beta cell mass expansion observed in Arrb2-global-knockout mice could be the indirect consequence of ARRB2 action in non-beta cells, such as insulin resistance from other tissues generating metabolic disturbances [21]. In 
addition, it should be mentioned that neuronal and systemic signals from liver have been reported to trigger the compensatory increase in beta cell number in insulin-resistant states [42-44], and such mechanisms could be defective in the absence of ARRB2. Future studies using beta-specific $A r r b 2^{-/-}$mice should determine if the defective beta cell mass expansion is due to a direct effect of ARRB2 on beta cells rather than a consequence of the absence of ARRB2 in the whole organism.

Pancreatic beta cell proliferation and survival are regulated by signalling pathways linked to GPCRs and RTKs such as IR [4,5]. The insulin signalling pathway in beta cells is mainly mediated through the IR/IRS/PI3K/Akt cascade [5,11,13]. Any deficiency of this pathway has been reported to induce beta cell failure by affecting the beta cell mass expansion $[11,13,45]$. Akt activation requires PI3K-mediated phosphatidylinositol 3,4,5-triphosphate (PIP3) synthesis, allowing its recruitment to the plasma membrane, where it is subsequently phosphorylated at Thr308 and Ser473 via the phosphoinositide-dependent kinase 1 and by the mammalian target of rapamycin complex 2, respectively [46]. In addition to this canonical PI3K/Akt pathway, ARRB2 was previously shown in hepatocytes to be required downstream of the IR for a full Akt activation [21]. Here, we found that insulin-induced Akt phosphorylation at Ser473 requires ARRB2-dependent mechanisms in mouse pancreatic islets. In beta cells, FOXO1 and GSK3 are two major targets of Akt which represses, by phosphorylation, the negative effects of FOXO1 and GSK3 on insulin production and beta cell mass. Indeed, Akt inactivates FOXO1 by phosphorylation, allowing its exclusion from the nucleus where it represses the expression of both insulin and pancreas/duodenum homeobox protein 1 (PDX1), a transcription factor involved in the maintenance of the beta cell mass $[38,47]$. Similarly, GSK3 $\beta$ seems to negatively regulate the beta cell mass by repressing the insulin signalling pathway and by reducing PDX1 levels in islets $[48,49]$. The involvement of ARRB2 in IR-Akt signalling is functionally relevant in vivo, as the phosphorylation of GSK3 and FOXO1, two Akt downstream targets, were strongly decreased 
on insulin stimulation in islets isolated from $A r r b 2^{-/-}$mice. Thus, our results suggest that ARRB2 could play a role in the control of pancreatic beta cell mass and insulin production through, at least in part, the insulin-Akt-GSK3 $\beta /$ FOXO1 signalling pathway. Full validation of the role of ARRB2 in the insulin signalling pathway awaits the results of further experiments testing the effects of an overexpression of an overexpression of the protein both in vitro and in vivo.

Besides IR, numerous GPCRs that could exhibit potential ARRB2-dependent signalling pathways are also involved in the regulation of beta cell mass $[4,40]$. It is also noteworthy that there is evidence for ARRB1 roles in GLP-1 mediation of cell survival and proliferation in clonal beta cell lines $[22,24,25]$. Indeed, we showed in INS-1E cells that ARRB1 is required for GLP-1R-mediated sustained ERK1/2 activation leading to IRS-2 expression [25], and it has recently been reported that ARRB1 is involved in the proliferative action of GLP-1 via the recruitment of c-Src in beta INS832/13 cells [24]. Additionally, we have reported in MIN6 cells that ARRB1 mediates anti-apoptotic effects of GLP-1 by phosphorylating the proapoptotic protein BAD through ERK1/2 activation [22].

Our results are in disagreement with the phenotype of $A r r b 2^{-/-}$mice previously reported by Luan et al [21]. First, in contrast to our study, their colony of $A r r b 2^{-/-}$mice exhibited hyperinsulinaemia in the re-fed state and in response to glucose load during glucose tolerance tests, an effect associated with lower insulin sensitivity and higher hepatic glucose production during hyperinsulinaemic-euglycaemic clamp studies in 8-week-old mice. The authors concluded on one hand that glucose intolerance associated with hyperinsulinaemia resulted from impaired insulin sensitivity [21], but on the other hand, they recently reported that glucose intolerance was due to impairment of insulin secretion as they observed impaired GSIS in vivo during a hyperglycaemic clamp and in vitro in static islet incubations [28].

The reason for the discrepancies between their results and our study is unclear, but the differences cannot result from differences in ages and/or experimental conditions. Indeed, in 
our study the defective insulin secretion in vivo and normal insulin sensitivity were not only observed in 6-7-month-old mice but also in 8-week-old animals (not shown). In addition, we have observed that in vitro GSIS is not affected in perifused or static incubated Arrb2 ${ }^{-/-}$islets, regardless the glucose concentration used. The differences between the two colonies of Arrb2 $2^{--}$mice might rather be explained by environmental/epigenetic phenomena and/or C57BL/6 mouse strain differences. Indeed, it is now clear that there are several C57BL/6 substrains with genetic differences for which different phenotypes have been reported [50].

In summary, we report that ARRB2 is not involved in GSIS or in GLP-1 or ACh potentiation of GSIS, but plays a key role in the modulation of the beta cell mass and, notably, contributes to the compensatory beta cell mass expansion in response to high-fat feeding through proliferation. In addition, we provide further new insights concerning the mechanisms of insulin action in pancreatic beta cells by showing that ARRB2 is required for full Akt activation by the hormone. 


\section{Acknowledgements}

The authors thank R. J. Lefkowitz (Duke University Medical Center, Durham, USA) for kindly providing $\mathrm{Arrb}^{-/}$mice, C. Bonnans (Institut de Génomique Fonctionnelle, Montpellier, France) for supplying and genotyping the animals, and L. Forichon and F. Rubio (Institut de Génomique Fonctionnelle, Montpellier, France) for technical assistance with the animals. The authors thank colleagues at the Reseau Histologie Expérimentale de Montpellier (Institut de Recherche en Cancérologie de Montpellier, Montpellier, France) and Montpellier Rio Imaging facilities (Institut des Neurosciences de Montpellier, Montpellier, France) for technical assistance.

\section{Funding}

This work was supported by the Centre National de la Recherche Scientifique, Institut National de la Santé et de la Recherche Médicale, Fondation pour la Recherche Médicale (grant DRM20101220453), research allocation from SFD-ALFEDIAM.

\section{Duality of interest}

The authors declare that there is no duality of interest associated with this manuscript.

\section{Contribution statement}

MAR contributed to the design, the acquisition, analysis and interpretation of the data and to the drafting/revision of the article. ML, JR, NL, AV, NP, MMR, SD and JB contributed to the acquisition and analysis of the data and to the revision of the manuscript. GB contributed to the conception and design of the study, the acquisition, analysis and interpretation of data and to drafting/revising the manuscript. All authors approved the final version to be published. 
Table 1 Quantification of $\left[\mathrm{Ca}^{2+}\right]_{\mathrm{c}}$ oscillations under glucose and GLP-1 stimulation G16.7 G16.7 + GLP-1

\begin{tabular}{|c|c|c|c|c|}
\hline Measure & $A r r b 2^{+/+}$ & Arrb2 $2^{-/-}$ & $A r r b 2^{+/+}$ & $A r r b 2^{-/-}$ \\
\hline Frequency $\left(\mathrm{min}^{-1}\right)$ & $0.234 \pm 0.010$ & $0.261 \pm 0.016^{\mathrm{a}}$ & $0.454 \pm 0.060^{* *}$ & $0.484 \pm 0.037^{* *, a}$ \\
\hline Nadir & $0.917 \pm 0.003$ & $0.919 \pm 0.003^{\mathrm{a}}$ & $0.987 \pm 0.011^{* *}$ & $0.969 \pm 0.010^{* *, a}$ \\
\hline Peak & $1.103 \pm 0.009$ & $1.092 \pm 0.006^{\mathrm{a}}$ & $1.109 \pm 0.009^{* *}$ & $1.096 \pm 0.005^{*}, \mathrm{a}$ \\
\hline Amplitude & $0.186 \pm 0.010$ & $0.173 \pm 0.007^{\mathrm{a}}$ & $0.122 \pm 0.010^{* *}$ & $0.137 \pm 0.007^{* *, a}$ \\
\hline
\end{tabular}

${ }^{*} p<0.05$ and ${ }^{* *} p<0.01$ compared with G16.7

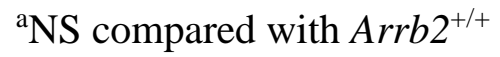

G16.7, $16.7 \mathrm{mmol} / \mathrm{l}$ glucose

Table 2 Quantification of $\left[\mathrm{Ca}^{2+}\right]_{\mathrm{c}}$ changes under ACh stimulation

\begin{tabular}{lcc}
\hline Measure & Arrb2 $^{+/+}$ & Arrb2 $^{-/-}$ \\
\hline Cells with a sustained level of $\left[\mathrm{Ca}^{2+}\right]_{\mathrm{c}}$ & $17 / 38(44.7 \%)$ & $16 / 37(43.2 \%)^{\mathrm{a}}$ \\
Frequency $\left(\mathrm{min}^{-1}\right)$ & $2.795 \pm 0.248$ & $3.467 \pm 0.265^{\mathrm{a}}$ \\
$\Delta$ response & $0.075 \pm 0.003$ & $0.085 \pm 0.004^{\mathrm{a}}$
\end{tabular}

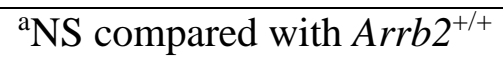




\section{Figure legends}

Fig. $1 \mathrm{Arrb} 2^{-/-}$mice displayed mild glucose intolerance and reduced plasma insulin levels. (a) Intraperitoneal glucose tolerance test: blood glucose levels were measured before and after an i.p. glucose injection (1.5 g/kg body weight) in $A r r b 2^{+/+}$vs $A r r b 2^{-/-}$mice. (b) Intraperitoneal insulin tolerance test: blood glucose levels were measured before and after the i.p. insulin injection $\left(0.75 \mathrm{U} / \mathrm{kg}\right.$ body weight) in $A r r b 2^{+/+}$vs $A r r b 2^{-/-}$mice. (c) During the glucose tolerance test, plasma insulin levels were measured before (0) and 15 min after the i.p. glucose injection. Blood glucose (d) and plasma insulin (e) levels in Arrb2 $2^{+/+}$vs Arrb2 $2^{-/-}$ mice fed ad libitum. Blood glucose (f) and plasma insulin (g) levels were measured before

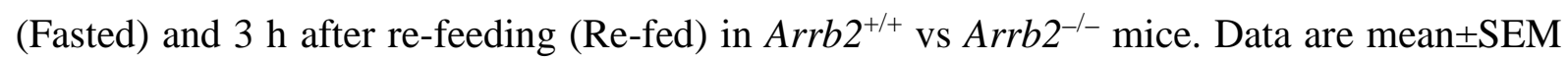
from 12-14 mice. ${ }^{*} p<0.05,{ }^{* *} p<0.01$ and ${ }^{* * *} p<0.001$ compared with $A r r b 2^{+/+}$mice. White, Arrb2 $2^{+/+}$; black, Arrb2 $2^{-/-}$

Fig. $2 A r r b 2^{-/-}$islets displayed normal glucose-induced $\left[\mathrm{Ca}^{2+}\right]_{\mathrm{c}}$ and insulin secretion changes but lower insulin content. Glucose-induced $\left[\mathrm{Ca}^{2+}\right]_{\mathrm{c}}$ changes (a) and insulin release (b,c) in $A r r b 2^{+/+}$vs $A r r b 2^{-/-}$mice. After overnight culture, batches of 30-40 islets were perifused for $30 \mathrm{~min}$ with $\mathrm{KRB}$ containing $1.1 \mathrm{mmol} / \mathrm{l}$ and then $16.7 \mathrm{mmol} / \mathrm{l}$ glucose for 40 min. (b) Inset, AUC (pg/islet in $7 \mathrm{~min}$ ) for the first phase of secretion (from 10 to $17 \mathrm{~min}$ ). Insulin content of isolated islets (d) and whole pancreas (e), and Ins 2 mRNA levels in islets (f) in $\mathrm{Arrb2}^{+/+}$vs $\mathrm{Arrb2} 2^{-/-}$islets. Ins 2 mRNA levels were determined by real-time quantitative RT-PCR on total islet RNA using a mouse-specific primer (see ESM Table 2) and normalised to the geometric mean of the expression levels of four housekeeping genes (Gus, Hprt, Gapdh and Tubb2). Data are mean \pm SEM from six to eight independent experiments or animals. ${ }^{*} p<0.05$ compared with Arrb2 $2^{+/+}$. Blue line/white symbols, Arrb2 $2^{+/+}$; red line/black symbols, Arrb2 ${ }^{-/-}$. G1.1, $1.1 \mathrm{mmol} / \mathrm{l}$ glucose; G16.7, $16.7 \mathrm{mmol} / \mathrm{l}$ glucose 
Fig. $3 A r r b 2^{-/-}$islets displayed normal responses to GLP-1 and ACh. The impact of GLP-1 $(20 \mathrm{nmol} / \mathrm{l})$ on $\left[\mathrm{Ca}^{2+}\right]_{\mathrm{c}}$ changes $(\mathbf{a})$ and insulin secretion $(\mathbf{b})$ in the presence of $16.7 \mathrm{mmol} / \mathrm{l}$ glucose. The impact of ACh $(1 \mu \mathrm{mol} / \mathrm{l})$ on $\left[\mathrm{Ca}^{2+}\right]_{\mathrm{c}}$ changes $(\mathbf{c})$ and insulin secretion $(\mathbf{d})$ in the presence of $11 \mathrm{mmol} / \mathrm{l}$ glucose in $A r r b 2^{+/+}$vs $A r r b 2^{-/-}$islets. (a,c) The two upper traces illustrate individual experiments while the two lower traces illustrate the average. (b,d) Insets, AUC (pg/islet/min) during either GLP-1 or ACh stimulation. Data are mean \pm SEM from five to six independent experiments or animals. Blue line/white symbols, Arrb2 $2^{+/+}$; red line/black symbols, Arrb2 ${ }^{-/-}$. G1.1, $1.1 \mathrm{mmol} / \mathrm{l}$ glucose; G16.7, $16.7 \mathrm{mmol} / \mathrm{l}$ glucose

Fig. $4 A r r b 2^{-/-}$mice displayed reduced beta cell mass. (a) Representative microphotographs of H\&E-stained pancreatic sections from $A r r b 2^{+/+}$or $A r r b 2^{-/-}$mice. (b) Islet number and (c) occupation of pancreatic section in $A r r b 2^{+/+}$vs $A r r b 2^{-/-}$pancreatic sections. (d) Distribution of islets according to their size (area) expressed as percentage of total islet number per pancreatic section in islets from $A r r b 2^{+/+}$and $A r r b 2^{-/-}$mice. (e) Representative immunofluorescence staining of insulin and glucagon from a pancreatic section. Nuclei have been labelled with DAPI. Quantification of beta and alpha cell number per islet (f) and beta cell size (g) within the islets from $A r r b 2^{+/+}$vs $A r r b 2^{-/-}$mice, using the calibrated ImageJ analysis program. ${ }^{*} p<0.05$ and ${ }^{* *} p<0.01$ compared with $A r r b 2^{+/+}$mice. White, Arrb2 $2^{+/+}$; black, Arrb2-/-

Fig. 5 ARRB2 is involved in insulin signalling in mouse pancreatic islets. Freshly isolated islets were distributed in batches of $120-150$, subjected to a $2 \mathrm{~h}$ quiescent period in bicarbonate KRB with $1.1 \mathrm{mmol} / \mathrm{l}$ glucose and then incubated with insulin $(100 \mathrm{nmol} / \mathrm{l})$ for 10 min. Representative immunoblots show the comparative effects of insulin on phosphorylation 
of Akt, FOXO1 and GSK3 in islets from Arrb2 $2^{+/+}$and $A r r b 2^{-/-}$mice; the graphs illustrate the quantitative analysis of increase in protein phosphorylation over basal level by densitometry using ImageJ. Data are mean \pm SEM from three to four independent experiments from 15-20 mice. ${ }^{* *} p<0.01$ and ${ }^{* * *} p<0.001$ compared with insulin treatment in $A r r b 2^{+/+}$islets. White, Arrb2 $2^{+/+}$; black, Arrb2 $2^{-/-}$

Fig. $6 A r r b 2^{-/-}$mice are unable to compensate their beta cell mass under HFD conditions. Islet occupation (a) and number (b) in H\&E-stained pancreatic sections from male Arrb2 $2^{+/+}$ and $A r r b 2^{-/-}$mice fed with ND or HFD from 8 weeks for 19 weeks. (c) Representative images of insulin and Ki67 immunofluorescence staining in pancreatic sections from male Arrb2 $2^{+/+}$ mice fed with either standard ND or HFD. Ki67-positive nuclei in beta cells are indicated with arrowheads. (d) beta cell number and (e) beta cell size within the islets from $A r r b 2^{+/+}$ and $A r r b 2^{-/-}$mice. (f) The beta cell mass was measured by multiplying the total area occupied by the insulin-positive cells in three pancreatic sections with the weight of the pancreas for each mouse. (g) Quantification of Ki67-positive beta cells expressed as percentage of beta cells per islet from $A r r b 2^{+/+}$and $A r r b 2^{-/-}$mice. Data are mean \pm SEM from four animals. ${ }^{*} p<0.05$ and ${ }^{* * *} p<0.001$. White, Arrb2 ${ }^{+/+}$; black, Arrb2 $2^{-/-}$ 


\section{References}

1. Butler AE, Janson J, Bonner-Weir S, Ritzel R, Rizza RA, Butler PC (2003) Beta-cell deficit and increased beta-cell apoptosis in humans with type 2 diabetes. Diabetes 52:102-110

2. Prentki M, Nolan CJ (2006) Islet beta cell failure in type 2 diabetes. J Clin Invest 116:1802-1812

3. Weir GC, Bonner-Weir S (2013) Islet beta cell mass in diabetes and how it relates to function, birth, and death. Ann NY Acad Sci 1281:92-105

4. Ahren B (2009) Islet G protein-coupled receptors as potential targets for treatment of type 2 diabetes. Nat Rev Drug Discov 8:369-385

5. Goldfine AB, Kulkarni RN (2012) Modulation of beta-cell function: a translational journey from the bench to the bedside. Diabetes Obes Metab 14(Suppl 3):152-160

6. Gilon P, Henquin JC (2001) Mechanisms and physiological significance of the cholinergic control of pancreatic beta-cell function. Endocr Rev 22:565-604

7. Thorens B (2011) Brain glucose sensing and neural regulation of insulin and glucagon secretion. Diabetes Obes Metab 13(Suppl 1):82-88

8. Campbell JE, Drucker DJ (2013) Pharmacology, physiology, and mechanisms of incretin hormone action. Cell Metab 17:819-837

9. Gautam D, Han SJ, Duttaroy A et al (2007) Role of the M3 muscarinic acetylcholine receptor in beta-cell function and glucose homeostasis. Diabetes Obes Metab 9(Suppl 2):158169

10. Leibiger IB, Leibiger B, Berggren PO (2008) Insulin signaling in the pancreatic beta-cell. Annu Rev Nutr 28:233-251

11. Assmann A, Hinault C, Kulkarni RN (2009) Growth factor control of pancreatic islet regeneration and function. Pediatr Diabetes 10:14-32

12. Braun M, Ramracheya R, Rorsman P (2012) Autocrine regulation of insulin secretion. Diabetes Obes Metab 14(Suppl 3):143-151

13. Elghazi L, Bernal-Mizrachi E (2009) Akt and PTEN: beta-cell mass and pancreas plasticity. Trends Endocrinol Metab 20:243-251

14. Kovacs JJ, Hara MR, Davenport CL, Kim J, Lefkowitz RJ (2009) Arrestin development: emerging roles for beta-arrestins in developmental signaling pathways. Dev Cell 17:443-458

15. Lefkowitz RJ, Shenoy SK (2005) Transduction of receptor signals by beta-arrestins. Science 308:512-517

16. Luttrell LM, Gesty-Palmer D (2010) Beyond desensitization: physiological relevance of arrestin-dependent signaling. Pharmacol Rev 62:305-330 
17. DeWire SM, Ahn S, Lefkowitz RJ, Shenoy SK (2007) Beta-arrestins and cell signaling. Annu Rev Physiol 69:483-510

18. Whalen EJ, Rajagopal S, Lefkowitz RJ (2011) Therapeutic potential of beta-arrestin- and G protein-biased agonists. Trends Mol Med 17:126-139

19. DeFea KA (2011) Beta-arrestins as regulators of signal termination and transduction: how do they determine what to scaffold? Cell Signal 23:621-629

20. Hupfeld CJ, Olefsky JM (2007) Regulation of receptor tyrosine kinase signaling by GRKs and beta-arrestins. Annu Rev Physiol 69:561-577

21. Luan B, Zhao J, Wu H et al (2009) Deficiency of a beta-arrestin-2 signal complex contributes to insulin resistance. Nature 457:1146-1149

22. Quoyer J, Longuet C, Broca C et al (2010) GLP-1 mediates antiapoptotic effect by phosphorylating Bad through a beta-arrestin 1-mediated ERK1/2 activation in pancreatic betacells. J Biol Chem 285:1989-2002

23. Sonoda N, Imamura T, Yoshizaki T, Babendure JL, Lu JC, Olefsky JM (2008) BetaArrestin-1 mediates glucagon-like peptide-1 signaling to insulin secretion in cultured pancreatic beta cells. Proc Natl Acad Sci USA 105:6614-6619

24. Talbot J, Joly E, Prentki M, Buteau J (2012) beta-Arrestin1 mediated recruitment of c-Src underlies the proliferative action of glucagon-like peptide-1 in pancreatic beta INS832/13 cells. Mol Cell Endocrinol 354:65-70

25. Broca C, Quoyer J, Costes S et al (2009) beta-Arrestin 1 is required for PAC1 receptormediated potentiation of long-lasting ERK1/2 activation by glucose in pancreatic beta-cells. J Biol Chem 284:4332-4342

26. Kong KC, Butcher AJ, McWilliams P et al (2010) M3-muscarinic receptor promotes insulin release via receptor phosphorylation/arrestin-dependent activation of protein kinase D1. Proc Natl Acad Sci USA 107:21181-21186

27. Dalle S, Ravier MA, Bertrand G (2011) Emerging roles for beta-arrestin-1 in the control of the pancreatic beta-cell function and mass: new therapeutic strategies and consequences for drug screening. Cell Signal 23:522-528

28. Zhang M, Zhu Y, Mu K et al (2013) Loss of beta-arrestin2 mediates pancreatic-islet dysfunction in mice. Biochem Biophys Res Commun 435:345-349

29. Bertrand G, Ishiyama N, Nenquin M, Ravier MA, Henquin JC (2002) The elevation of glutamate content and the amplification of insulin secretion in glucose-stimulated pancreatic islets are not causally related. J Biol Chem 277:32883-32891

30. Kahn SE, Hull RL, Utzschneider KM (2006) Mechanisms linking obesity to insulin resistance and type 2 diabetes. Nature 444:840-846 
31. Sachdeva MM, Stoffers DA (2009) Minireview: Meeting the demand for insulin: molecular mechanisms of adaptive postnatal beta-cell mass expansion. Mol Endocrinol 23:747-758

32. Syme CA, Zhang L, Bisello A (2006) Caveolin-1 regulates cellular trafficking and function of the glucagon-like Peptide 1 receptor. Mol Endocrinol 20:3400-3411

33. Jorgensen R, Martini L, Schwartz TW, Elling CE (2005) Characterization of glucagonlike peptide-1 receptor beta-arrestin 2 interaction: a high-affinity receptor phenotype. Mol Endocrinol 19:812-823

34. Jorgensen R, Kubale V, Vrecl M, Schwartz TW, Elling CE (2007) Oxyntomodulin differentially affects glucagon-like peptide- 1 receptor beta-arrestin recruitment and signaling through Galpha(s). J Pharmacol Exp Ther 322:148-154

35. Schelshorn D, Joly F, Mutel S, Hampe C, Breton B, Mutel V, Lutjens R (2012) Lateral allosterism in the glucagon receptor family: glucagon-like peptide 1 induces G-proteincoupled receptor heteromer formation. Mol Pharmacol 81:309-318

36. Alejandro EU, Lim GE, Mehran AE et al (2011) Pancreatic beta-cell Raf-1 is required for glucose tolerance, insulin secretion, and insulin 2 transcription. FASEB J 25:3884-3895

37. Gu C, Stein GH, Pan N et al (2010) Pancreatic beta cells require NeuroD to achieve and maintain functional maturity. Cell Metab 11:298-310

38. Meur G, Qian Q, da Silva Xavier G et al (2011) Nucleo-cytosolic shuttling of FoxO1 directly regulates mouse Ins2 but not Ins 1 gene expression in pancreatic beta cells (MIN6). J Biol Chem 286:13647-13656

39. Lee YC, Nielsen JH (2009) Regulation of beta cell replication. Mol Cell Endocrinol 297:18-27

40. Gunasekaran U, Hudgens CW, Wright BT, Maulis MF, Gannon M (2012) Differential regulation of embryonic and adult beta cell replication. Cell Cycle 11:2431-2442

41. Thorens B (2013) The required beta cell research for improving treatment of type 2 diabetes. J Intern Med 274:203-214

42. Imai J, Katagiri H, Yamada $\mathrm{T}$ et al (2008) Regulation of pancreatic beta cell mass by neuronal signals from the liver. Science 322:1250-1254

43. El Ouaamari A, Kawamori D, Dirice E et al (2013) Liver-derived systemic factors drive beta cell hyperplasia in insulin-resistant states. Cell Rep 3:401-410

44. Yi P, Park JS, Melton DA (2013) Betatrophin: a hormone that controls pancreatic beta cell proliferation. Cell 153:747-758

45. Buzzi F, Xu L, Zuellig RA et al (2010) Differential effects of protein kinase B/Akt isoforms on glucose homeostasis and islet mass. Mol Cell Biol 30:601-612 
46. Sarbassov DD, Guertin DA, Ali SM, Sabatini DM (2005) Phosphorylation and regulation of Akt/PKB by the rictor-mTOR complex. Science 307:1098-1101

47. Kitamura T, Nakae J, Kitamura Y et al (2002) The forkhead transcription factor Foxo1 links insulin signaling to $\mathrm{Pdx} 1$ regulation of pancreatic beta cell growth. $\mathrm{J}$ Clin Invest 110:1839-1847

48. Liu Y, Tanabe K, Baronnier D, Patel S, Woodgett J, Cras-Meneur C, Permutt MA (2010) Conditional ablation of Gsk-3beta in islet beta cells results in expanded mass and resistance to fat feeding-induced diabetes in mice. Diabetologia 53:2600-2610

49. Liu Z, Tanabe K, Bernal-Mizrachi E, Permutt MA (2008) Mice with beta cell overexpression of glycogen synthase kinase-3beta have reduced beta cell mass and proliferation. Diabetologia 51:623-631

50. Zurita E, Chagoyen M, Cantero M et al (2011) Genetic polymorphisms among C57BL/6 mouse inbred strains. Transgenic Res 20:481-489 


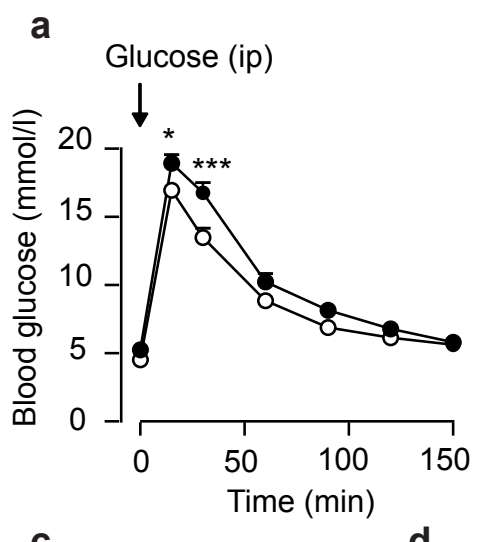

b
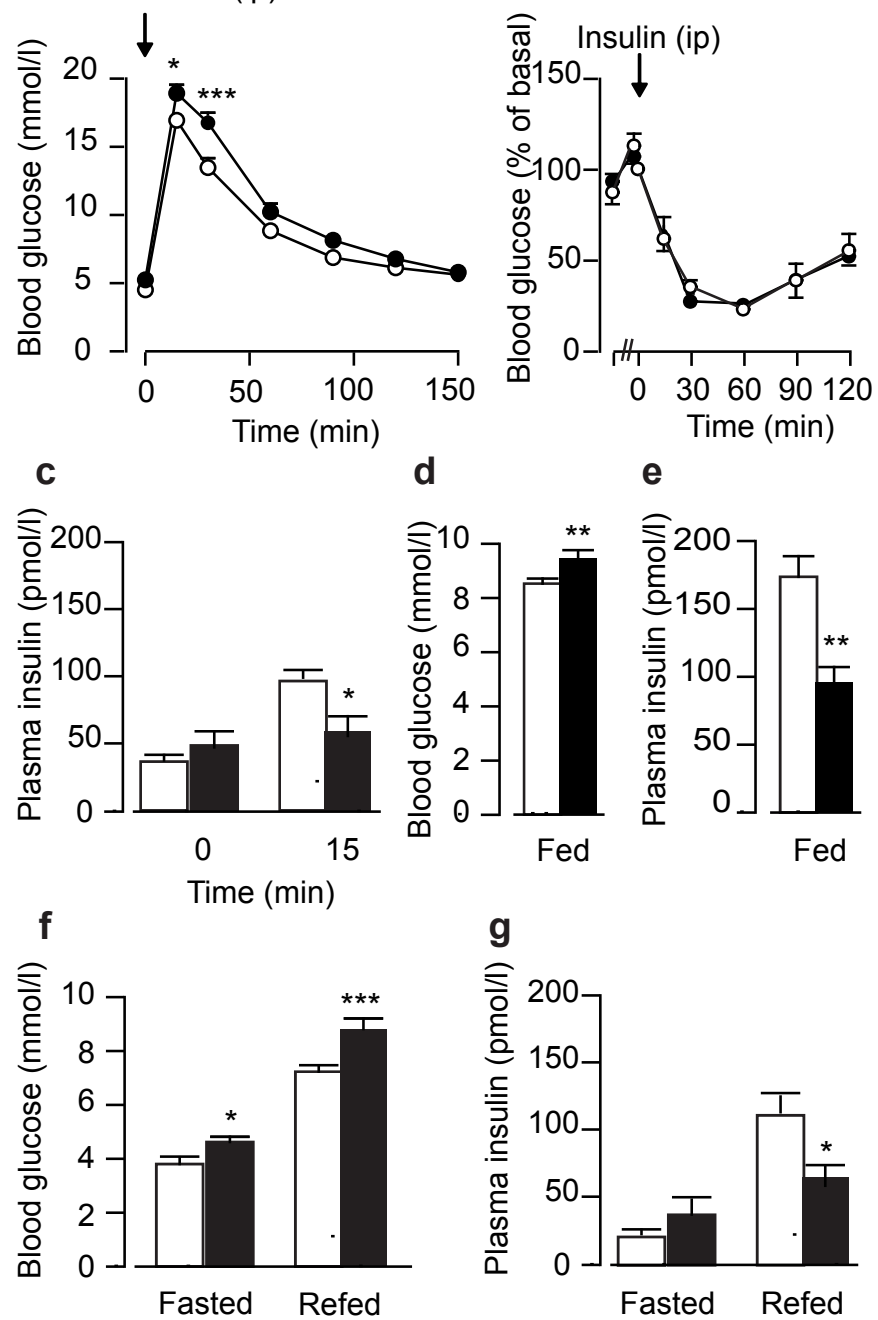

Fig. 1 

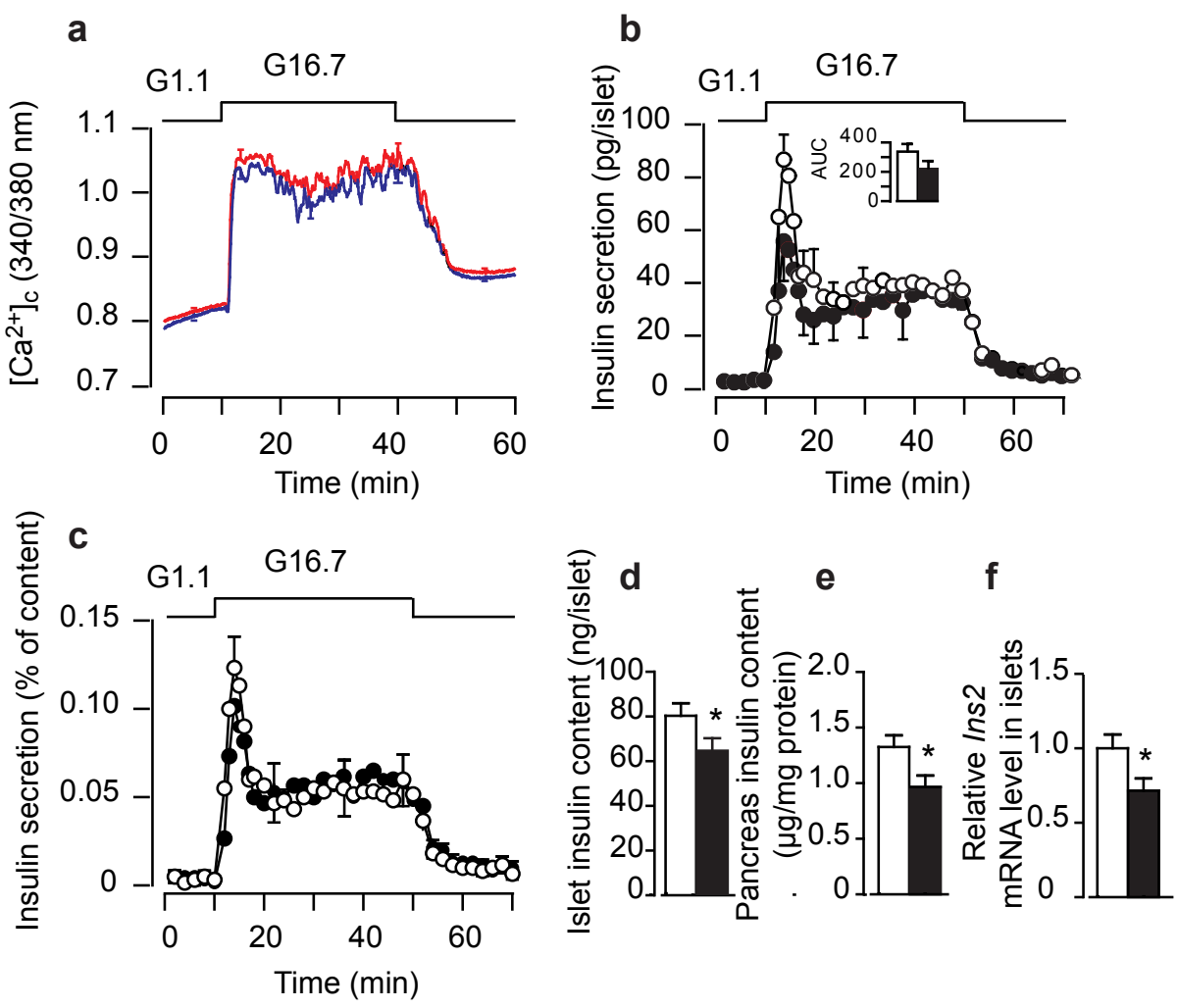

Fig. 2 

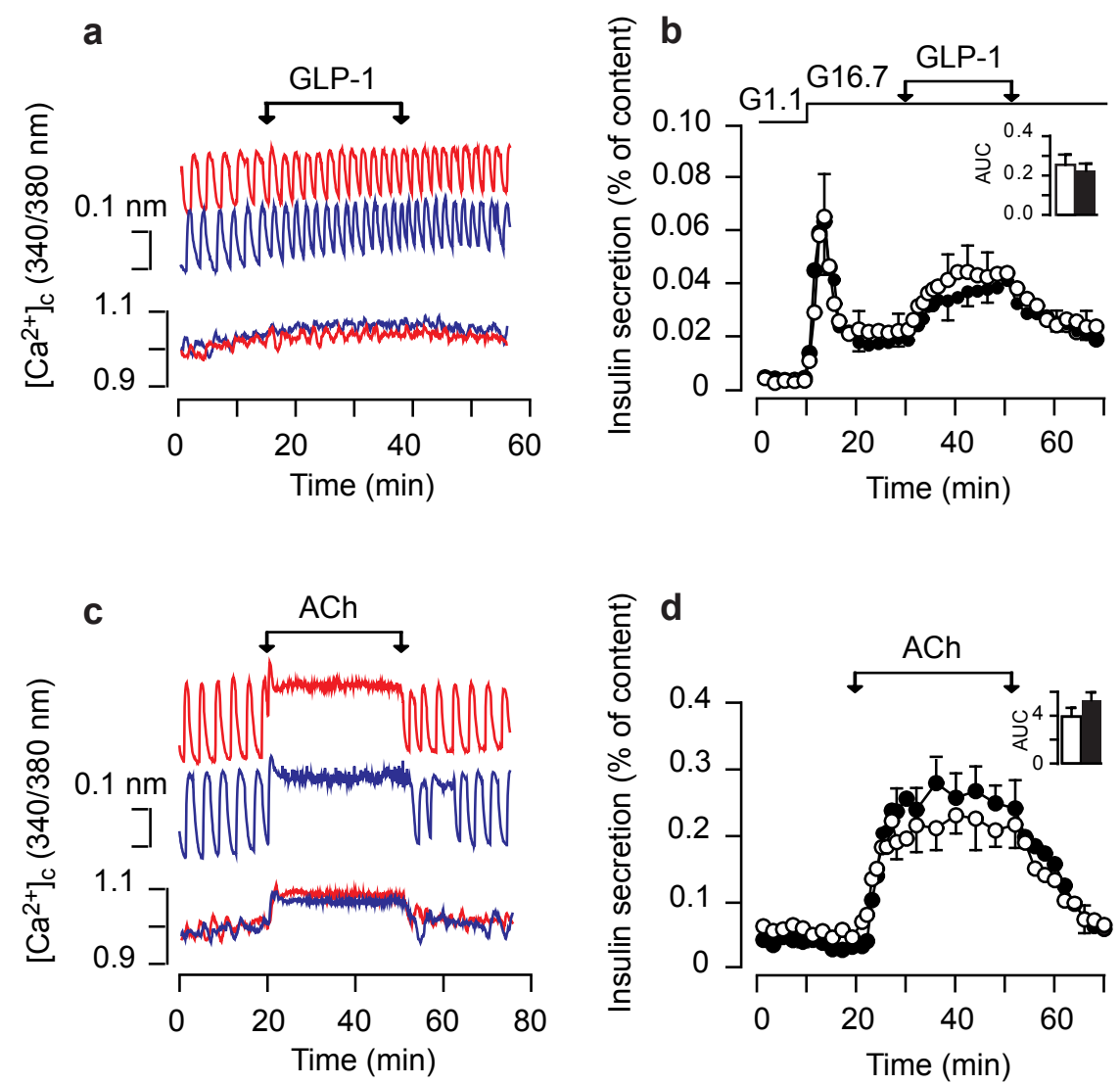

Fig. 3 
a Arrb2 $^{+/+}$
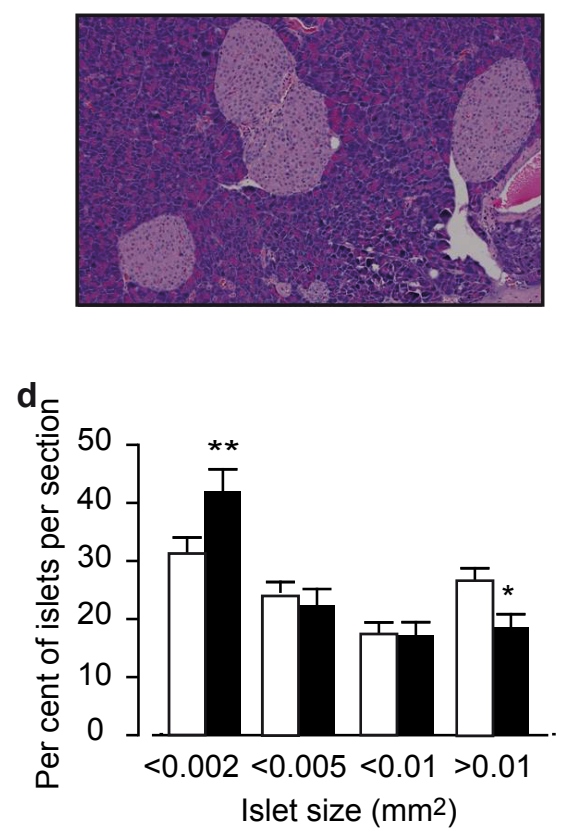

Arrb2 -/-
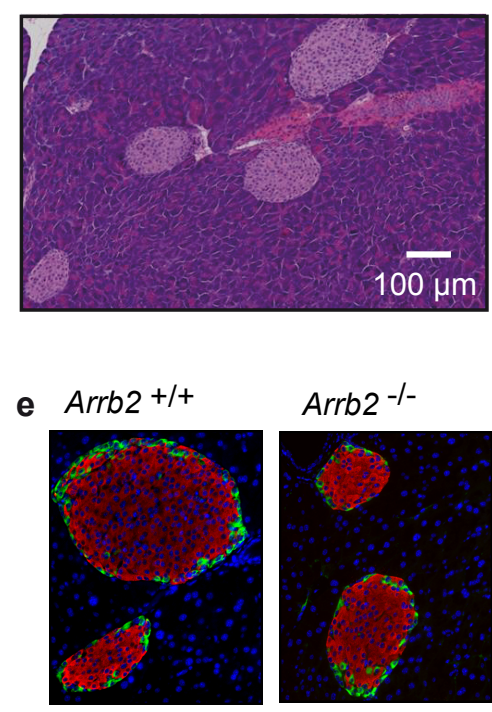

Insulin Glucagon DAPI $\quad \overline{100 \mu \mathrm{m}}$

Arrb2 -/-

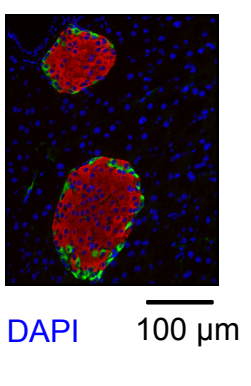

b
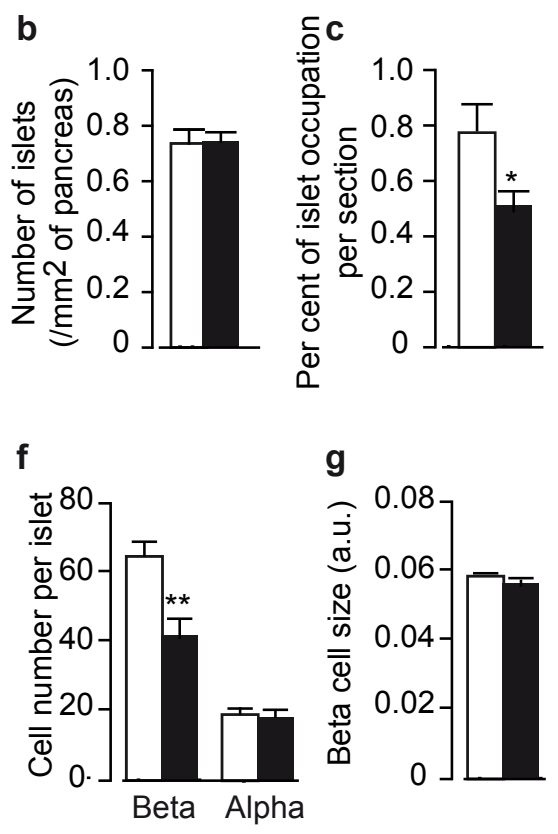

Fig. 4 


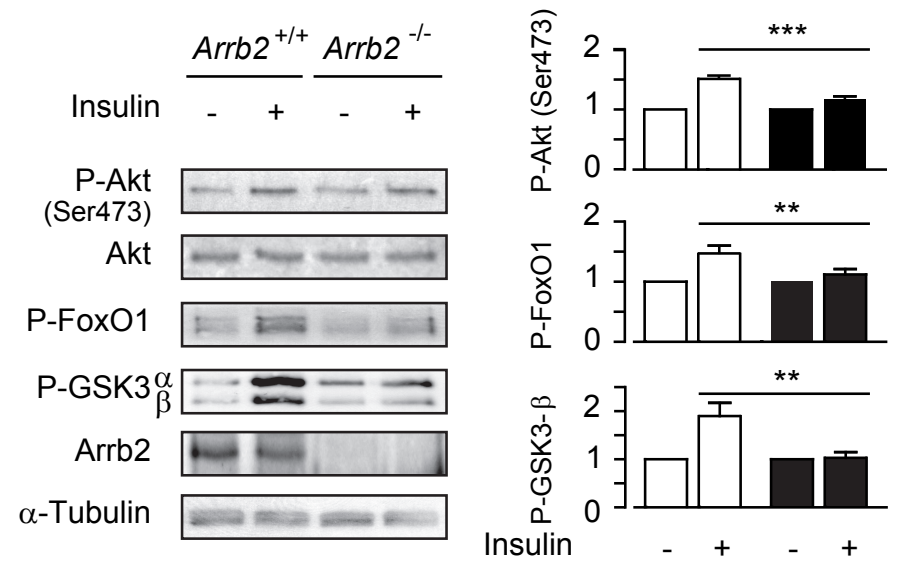

Fig. 5 

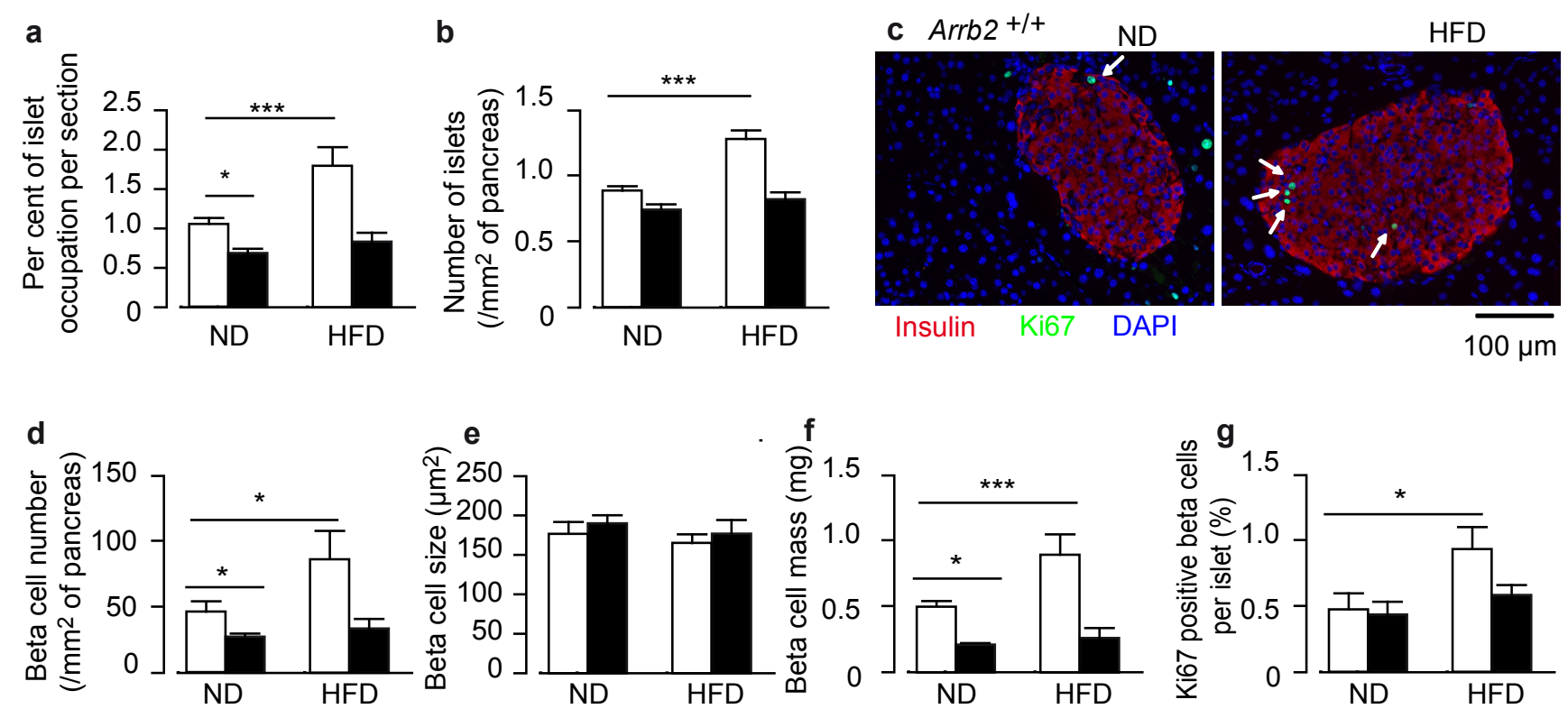

Fig. 6 

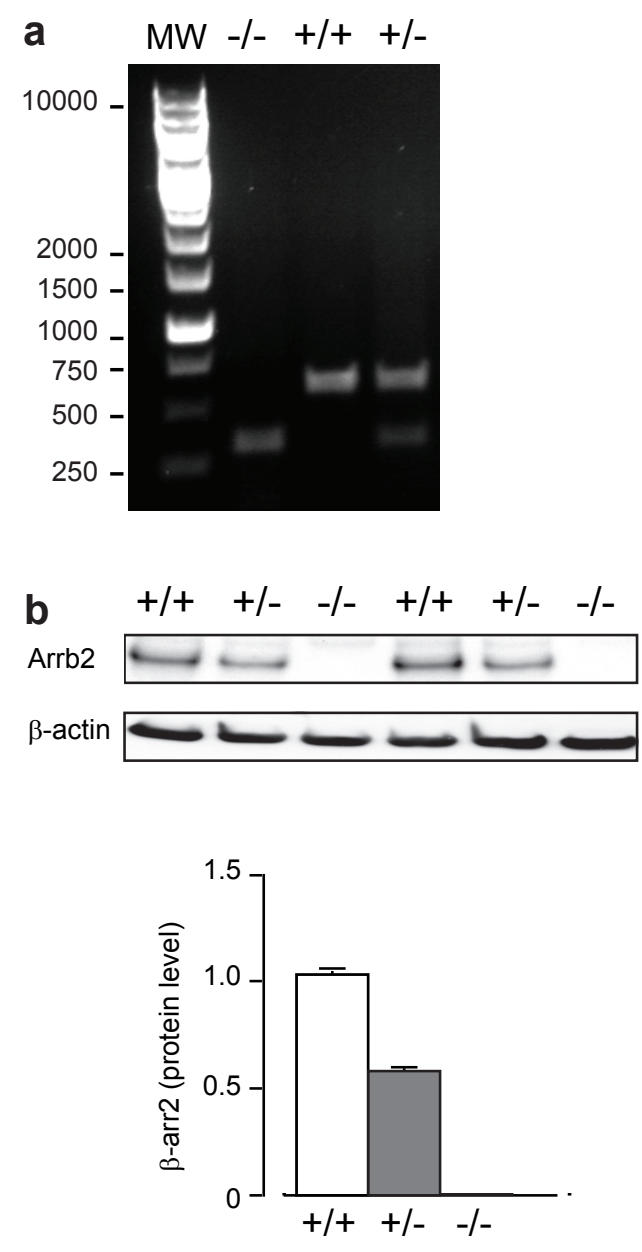

Fig S1. Genotyping and Arrb2 protein expression in Arrb2 ${ }^{+/+}$, Arrb2 $2^{+/-}$and Arrb2 $2^{-/-}$mice.

(a) Mouse genotyping was performed by PCR using Arrb2WT-forward GATCAAAGCCCTCGATGATC (intron 2) and Arrb2KO-forward GCTAAAGCGCATGCTCCAGA (Neo), which are specific for wild type (WT) and knockout (KO), respectively, and the primer Arrb2-reverse ACAGGGTCCACTTTGTCCA (exon 3) which is common for both WT and KO. Amplicon lenghts are $605 \mathrm{bp}$ and $300 \mathrm{bp}$ for Arrb2 $2^{+/+}$and Arrb2 $2^{-/-}$alleles, respectively. (b) Representative immunoblots and quantitative analysis by densitometry using Image $\mathrm{J}$, of Arrb2 protein from spleen of Arrb2 $2^{+/+}$, Arrb2 $2^{+/-}$and Arrb2 ${ }^{-/-}$mice. 


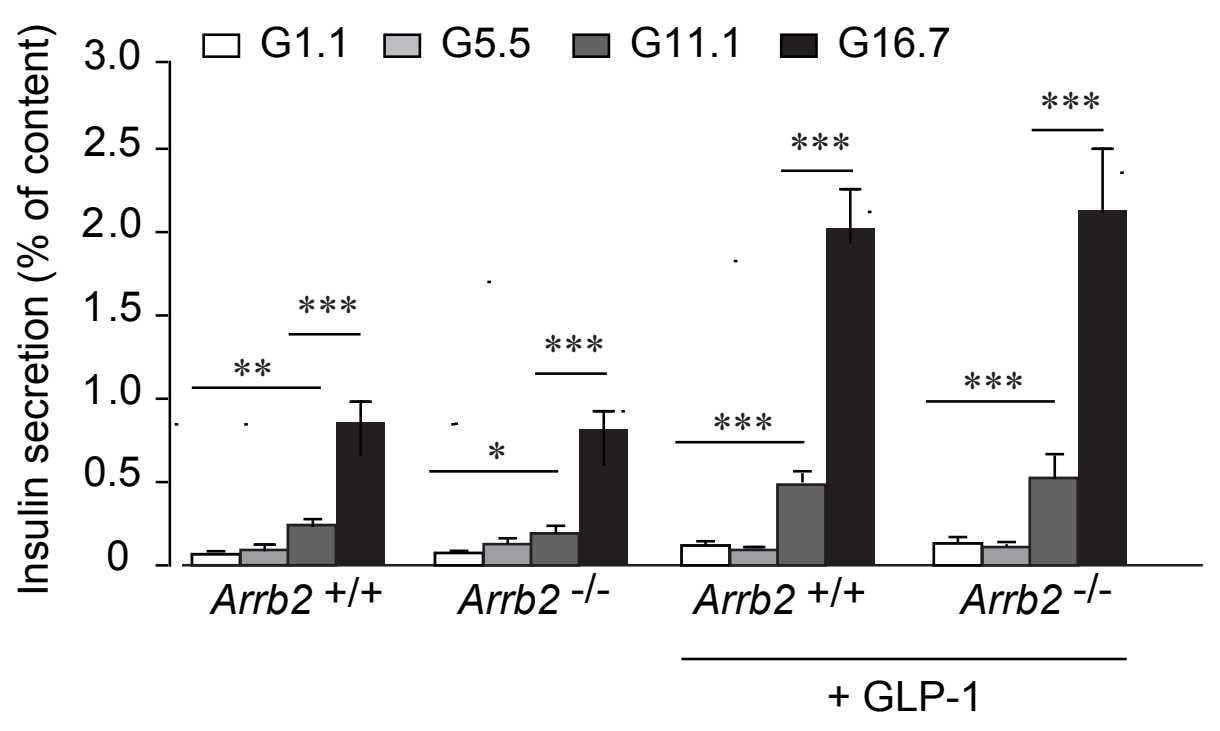

Fig S3. Insulin secretion from Arrb2 -/- and Arrb2 +/+ incubated islets. After overnight culture, batches of 5 islets were preincubated for $45 \mathrm{~min}$ in $5.5 \mathrm{mmol} / 1$ glucose (G5.5) before being incubated for $60 \mathrm{~min}$ in $1.1(\mathrm{G} 1.1), 5.5(\mathrm{G} 5.5), 11.1$ (G11.1) or 16.7 (G16.7) $\mathrm{mmol} / 1$ glucose in the presence or absence of $20 \mathrm{nmol} / 1 \mathrm{GLP}-1$, as indicated.

${ }^{* *} \mathrm{p}<0.01, * * * \mathrm{p}<0.005$. Data are mean \pm SEM from 4 independent experiments and animals. 
a
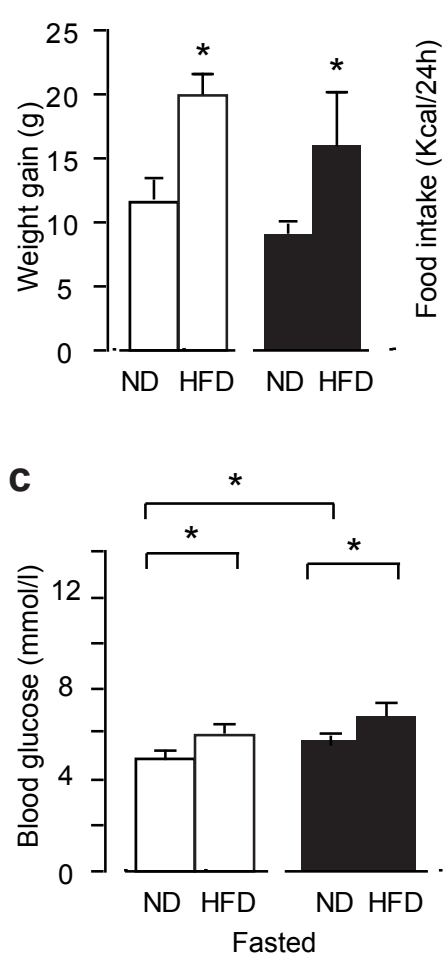

b

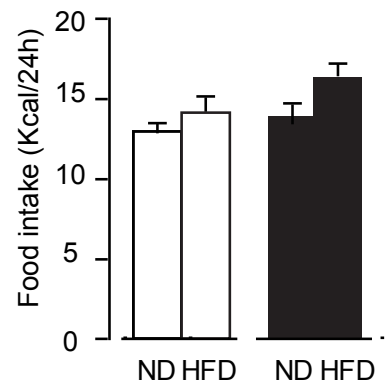

d

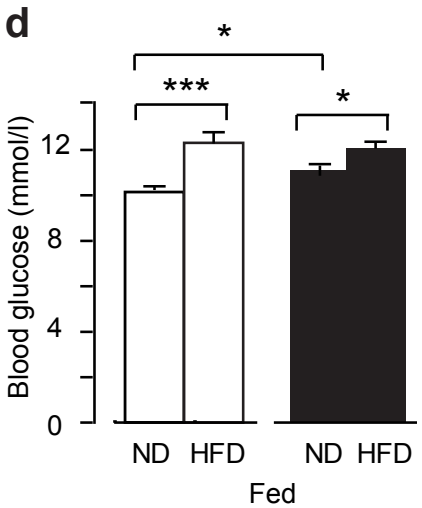

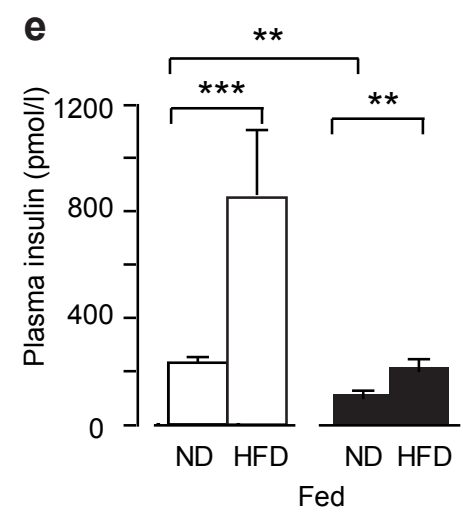

Fig S2. In vivo characteristics of Arrb2-/- (white bars) and Arrb2 $2^{+/+}$(black bars) mice fed with either a ND or a HFD. (a) Weight gain after 19 weeks of diet. (b) Food intake monitored during 24h in metabolic cages after 17 weeks of diet. (c) Blood glucose levels were measured after an overnight fast (Fasted) or in a fed ad libitum animals (Fed) (d). (e) Measurement of plasma insulin in fed ad libitum mice.

$* \mathrm{p}<0.05, * * \mathrm{p}<0.01, * * * \mathrm{p}<0.005$. Data are mean \pm SEM for $5(\mathrm{a}, \mathrm{b})$ or $8-13$ (c-e) separate animals. 